\title{
PENINGKATAN MUTU PENDIDIKAN MELALUI IMPLEMENTASI MANAJEMEN PENINGKATAN MUTU BERBASIS SEKOLAH (MPMBS) PADA MTSN DI KOTA BENGKULU
}

\author{
Hj. Khairiah ${ }^{1}$ \\ Email; khairiah@iainbengkulu.ac.id \\ H. Syarifuddin² \\ Email; Syarifuddin273@gmail.com
}

\begin{abstract}
ABSTRAC: Theobjective of this research was to describe the implementation of the school-based management quality in achieving the educational quality at the public MTs in Kota Bengkulu. The design of this research used a descriptive one the data were collected by using a set of instrument; i.e. interview, observationand documentation. The results ahow that the otonomi, responsibility, authority, participation, transparency, accountability, equality, equity and sustainability has not yet been optimally applied. So it can be suggested if you want to improve the quality of education then implement the program MPMBS.

Key Word: Implementation, School-Based Managemen Quality

Abstrak: Tujuan penelitian ini adalah untuk mendeskripsikan penerapan manajemen mutu berbasis sekolah dalam mencapai kualitas pendidikan di MTs negeri di Kota Bengkulu. Desain penelitian ini menggunakan metode deskriptif kualitatif yaitu pengumpulan data menggunakan seperangkat instrumen; yaitu wawancara, observasi dan dokumentasi. Hasilnya menunjukkan bahwa azas otonomi, tanggungjawab, kewenangan, partisipasi, transparansi, akuntabilitas, pemerataan, keadilan dan azas keberlanjutan belum optimal diterapkan. Maka disarankan jika ingin meningkatkan mutu pendidikan maka implementasikan program MPMBS.
\end{abstract}

Kata kunci: Implementasi, Kualitas Manajemen Berbasis Sekolah

\section{Pendahuluan}

Rendahnya mutu pendidikan merupakan permasalahan yang dihadapi dewasa ini pada setiap jenjang pendidikan, khususnya pendidikan dasar dan pendidikan menengah. Sesuai Depdiknas mutu pendidikan tidak mengalami peningkatan signifikan disebabkan 3 (tiga) faktor; 1) kebijakan dan penyelenggaraan pendidikan nasional menggunakan pendekatan educational production function tidak dilaksanakan secara konsekuen (terpusat pada input, kurang memperhatikan proses); 2) penyelenggaraan pendidikan dilakukan secara sentralistik, sehingga sekolah sangat tergantung pada keputusan birokrasi, kadang-kadang kebijakan yang dikeluarkan tidak sesuai dengan kondisi sekolah setempat; 3) peran serta masyarakat, khususnya orang tua siswa dalam penyelenggaraan pendidikan selama ini sangat minim, partisipasi masyarakat selama ini<smiles>[C]1[C]=C1</smiles>

lebih banyak bersifat dukungan dana, bukan pada proses pendidikan. ${ }^{3}$

Sejalan dengan diberlakukannya Undang-undang Nomor 20 Tahun 2003 tentang sistem pendidikan nasional, yang tidak membedakan Madrasah dengan Sekolah Umum, maka wajar Kementerian Agama memikirkan program yang dikembangkan oleh Kementerian Pendidikan dan Kebudayaan. Dalam hal ini Madrasah bisa mengimplementasikan manajemen berbasis madrasah (madrasah based managemen), agar bisa setara dengan sekolah umum dalam peningkatanan mutu pendidikannya.

'Khairiah. Kepala Biro AUAK IAIN Bengkulu

${ }^{2}$ Syarifuddin. Dosen FMIPA Universitas Bengkulu

${ }^{3}$ Depdiknas. 2004. Manajemen Berbasis Sekolah. (Jakarta: Direktorat Jenderal Pendidikan Dasar dan Menengah, 2004), h. 2 
9 NUANSA Vol. XI, Khạ, inimahorgyarifuddin | Peningkatan Mutu Pendidikan Melalui Implementasi Manajemen 9

Madrasah sebagai suatu bentuk satuan pendidikan, tentunya diharapkan dapat meningkatkan mutu, efisiensi dan efektifitas dalam penyelenggaraan pendidikannya. Dari hal demikian telah dilakukan upaya perbaikan, diantaranya sekarang dikembangkan adalah reorientasi penyelenggaraan pendidikan melalui manajemen peningkatan mutu berbasis sekolah (MPMBS). Studi Asmawi (2005) menunjukkan peran komite sekolah dalam kerangka manajemen peningkatan mutu, meningkatkan kualitas lulusan di SMKN 2 Arga Makmur. ${ }^{4}$ Studi Zulhendri (2005) menunjukkan Implementasi manajemen peningkatan mutu berbasis sekolah di SMA Negeri 5 Kota Bengkulu menunjukkan out put, proses dan input dalam rangka implementasi MPMBS adalah katagori baik. ${ }^{5}$ Studi Rustam (2005) menunjukkan jika pelaksanaan manajemen berbasis sekolah (MBS) pada SMPN 1 Kepahiang dilaksanakan secara baik, maka dapat meningkatkan mutu pendidikan SMPN 1 Kepahiang. ${ }^{6}$

Manajemen Peningkatan Mutu Berbasis Sekolah (MPMBS) atau disebut Delegated management, school all otonomy dan Local management of school. Maksudnya pendekatan yang bermuara kepada konsep desentralisasi pengelolaan pendidikan sampai pada level sekolah atau pengelolaan secara mandiri oleh sekolah.

Manajemen Peningkatan Mutu Berbasis Sekolah (MPMBS) yang sesungguhnya perlu diimplementasikan pada semua sekolah khususnya Madrasah yang dikelola oleh Kementerian Agama. Mengingat mutu MadrasahMTs Negeri dan Swasta di Kota Bengkulu dapat dilihat dari out put seperti; hasil Ujian Nasional (UN) MTsNegeri/Swasta yang ada di Kota Bengkulu sebanyak 8 (delapan) Madrasah, data Tahun 2017 menunjukkan bahwa MTsN 1 Tingkat kelulusan dengan nilai total rata-rata 50.00. MTsN 2 Tingkat kelulusan dengan nilai ratarata 43.13. MTs Pancasila Tingkat kelulusan dengan nilai total rata-rata 43.22. MTs Darussalam Tingkat kelulusan dengan nilai total rata-rata 39.08.MTs Al Quran Harsallakum Tingkat kelulusan dengan nilai

${ }^{4}$ Asmawi. Peran Komite Sekolah Dalam Kerangka Manajemen Peningkatan Mutu Berbasis Sekolah Untuk Meningkatkan Kualitas Lulusan D SMKN 2 Arga Makmur. 2005

${ }^{5}$ Zulhendri. Implementasi Manajemen Peningkatan Mutu Berbasis Sekolah di SMAN 5 Kota Bengkulu. 2005

${ }^{6}$ Rustam. Pelaksanaan Manajemen Berbasis Sekolah (MBS) Pada SMPN 1 Kepahiang Kabupaten Kepahiang. 2005 total rata-rata 49.75. MTs Almubarak Tingkat kelulusan dengan nilai total rata-rata 37.92. MTs Muhammadiyah. Tingkat kelulusan dengan nilai total ratarata 37.73. Mts Ja'alhaq. Tingkat kelulusan dengan nilai total rata-rata $52.89 .^{7}$ Ternyata masih jauh dari harapan.

Kemudian pada sisi pendidik dan tenaga kependidikan. Azyumardi, Madrasah masih hanya mampu memiliki jumlah pendidik dan tenaga kependidikan lainnya sangat terbatas, dari sinilah muncul kecenderungan kuat bagi banyaknya pendidik dan tenaga kependidikan yang salah kamar (mismatch), kualitas keilmuan yang tidak memadai, hanya seki$\operatorname{tar} 20 \%$ dari total guru madrasah yang layak (qualified), $20 \%$ mismatch dan $60 \%$ belum atau tidak layak (undercualified atau unqualified). ${ }^{8}$ Bahrul Hayat banyaknya guru madrasah (25\%) mengajar tidak pada bidangnya (mis-matc) dan banyak guru madrasah (terutama guru Non PNS) yang menjadikan tugasnya sebagai pekerjaan sambilan karena sebagai guru di madrasah tidak mencukupi pemenuhan kebutuhan hidupnya. ${ }^{9}$

Untuk mengatasi permasalahan tersebut berbagai cara telah diupayakan pemerintah, antara lain pada tahun 1980-an telah diujicobakan model pembelajaran Cara Belajar Siswa Aktif (CBSA), selanjutnya pendekatan model pembelajaran Joyfull learning atau dikenal model pembelajaran PAKEM (pembelajaran aktif, efektif dan menyenangkan). Dan dalam bidang manajemen sekolah seperti telah dikemukakan dimuka diberlakukannya kebijakan Manajemen Peningkatan Mutu Berbasis Sekolah (MPMBS) dan ini harus diimplementasikan dengan baik dan benar.Implementasi dan kebijakan sama pentingnya kalau tidak malah lebih penting dari pengambilan keputusan, suatu kebijakan akan tetap merupakan impian atau cetak biru jika tidak diimplementasikan. ${ }^{10}$

'Rekapitulasi Hasil Ujian Nasional (UN) http://puspendik.kemendikbud.go.id)

${ }^{8}$ Azyumardi. Masalah dan Kebijakan Pendidikan Islamdi Era Otonomi Daerah. Makalah yang disampaikan pada konferensi Nasional Manajemen Pndidikan Yang Dilaksanakan di Hotel Indonesia Jakarta pada Tanggal 8 s.d 10 Agustus 2002, h. 6-7

${ }^{9}$ Bahrul Hayat, Kumpulan Pidato, sekretaris Jenderal Kementerian Agama RI, (Jakarta:2013), h.199

${ }^{10}$ Udoji. C.J.O. The African public servant as a public policy maker. Pub-

$\begin{array}{llr}\text { lic Policy in Africa, African Association for Public Administration and Man- } \\ \text { agement, } & 1981, & \text { h. }\end{array}$ 


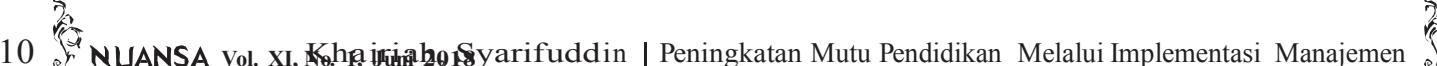

Dari kenyataan yang ada menunjukkan betapa kebanyakan pemerintah baru mampu mengesahkan kebijakan, tetapi belum mampu mengimplementasikannya sehingga dampak atau perubahan yang diharapkan tidak dapat diwujudkan.

Implementasi merupakan persoalan besar, banyak rencana dan program dibuat dan proyek-proyek inovasi diluncurkan, meskipun tidak sedikit rencana dan program tersebut yang berhasil mencapai sasarannya, tidak sedikit pula yang mengalami kesulitan dalam implementasinya. Ahmadi menyebutkan kesenjangan implementasi adalah suatu keadaan terjadi perbedaan antara yang diharapkan/direncanakan dengan kenyataan yang terjadi. Besar kecilnya kesenjangan tersebut banyak ditentukan oleh implementasi capacity, yaitu kmampuan aktor dalam mengimplementasi suatu kebijakan, namun kegagalan tersebut bisa juga disebabkan oleh pelaksanaannya yang jelek (bad execution), kebijakan itu sendiri yang jelek (bad policy), atau kebijakan itu sendiri yang bernasib buruk (bad luck).

Dari kenyataan yang ada pada MTsdi Kota Bengkulu, meski sudah diimplementasikannya MPMBS, namun masih banyak keluhan yang didapatkan bahkan para guru dan masyarakat dalam perlibatan atau partisipasi masyarakat masih bersifat kewajiban untuk mendukung input pendidikan tertentu, misalnya pendanaandan bukan pada sektor pendidikan misalnya pengambilan keputusan, monitoring, evaluasi dan akuntabilitas.

Dengan demikian, berdasarkan hal tersebut, maka penulis berkeinginan untuk melakukan kajian tentang upaya peningkatan mutu pendidikan melalui implementasi manajemen peningkatan mutu berbasis sekolah (MPMBS), yang nantinya diharapkan dapat meminimalkan masalah tersebut. Dengan menggunakan metode deskriptif kualitatif pendekatan fenomenologik dan model Winddelband dengan pertimbangan bahwa gejala dalam tulisan ini merupakan proses pengimplementasian MPMBS melalui kajian terhadap perilaku aktivitas dari stakeholders pendidikan yang terlibat didalamnya dan secara konseptual program tersebut menggunakan konteks dan desain lokal sesuai karakteristik lingkungan sekolah yang diungkapkan secara deskriptif. ${ }^{11}$

${ }^{11}$ Ahmady, Arifin, Zainal. 1995. Reformasi Adminitrasi dalam Pendidikan Beberapa Pelajaran tentang Implementasi Kebijakan. Pidato disampaikan pada Pengukuhan Jagatan Guru Besar dalam Ilmu Administrasi, Fakultas Administrasi Univrsitas Brawijaya Malang, Tanggal 13 Mei 1995, h. 4
Dari kenyataan yang ada pada MTsdi Kota Bengkulu, meski sudah diimplementasikannya MPMBS, namun masih banyak keluhan yang didapatkan bahkan para guru dan masyarakat dalam perlibatan atau partisipasi masyarakat masih bersifat kewajiban untuk mendukung input pendidikan tertentu, misalnya pendanaandan bukan pada sektor pendidikan misalnya pengambilan keputusan, monitoring, evaluasi dan akuntabilitas.

Dengan demikian, berdasarkan hal tersebut, maka penulis berkeinginan untuk melakukan kajian tentang upaya peningkatan mutu pendidikan melalui implementasi manajemen peningkatan mutu berbasis sekolah (MPMBS), yang nantinya diharapkan dapat meminimalkan masalah tersebut. Dengan menggunakan metode deskriptif kualitatif pendekatan fenomenologik dan model Winddelband dengan pertimbangan bahwa gejala dalam tulisan ini merupakan proses pengimplementasian MPMBS melalui kajian terhadap perilaku aktivitas dari stakeholders pendidikan yang terlibat didalamnya dan secara konseptual program tersebut menggunakan konteks dan desain lokal sesuai karakteristik lingkungan sekolah yang diungkapkan secara deskriptif.

\section{Pembahasan}

Manajemen Berbasis Sekolah (MBS) merupakan bentuk reformasi pendidikan pada prinsipnya sekolah memperoleh tanggung jawab (responsibility), kewewenang (authority) dan akuntabilitas (accountability) dalam meningkatkan kinerja sekolahdan manajemen berbasis sekolah (MBS) menyediakan layanan pendidikan yang menyeluruh dan tanggap terhadap kebutuhan masyarakat sekolah. Prinsip pemerataan (equality) dan keadilan (equity). ${ }^{12}$

Khusus dikalangan Kementerian Agama implementasi Manajemen Berbasis Madrasah (MBM) atau Madrasah Based Management (MBM) merupakan strategi mewujudkan madrasah yang efektif dan produktif. MBM merupakan paradigma baru manajemen pendidikan, memberikan otonomi luas pada madrasahdan perlibatan masyarakat dalam kerangka kebijakan pendidikan nasional, otonomi

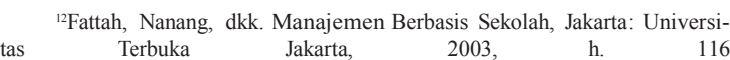




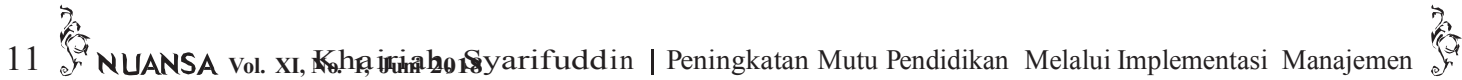

diberikan agar madrasah leluasa mengelola sumberdaya, sumber anggaran, sumber belajar dan mengalokasikannya sesuai prioritas kebutuhan serta lebih tanggap terhadap kebutuhan setempat. MBM merupakan ide tentang pengambilan keputusan pendidikan yang diletakkan pada posisi paling dekat dengan pembelajaran yakni madrasah. ${ }^{13}$

Menurut Allan Dornself, School based management describes a collection of practice in which more people at the school level make decisions for the school it often begins with decentralization; a delegation of certain powers from the central office to the school that may include any range of powerfoom a few, limited areas to nearly everything. ${ }^{14}$ Maksudnya manajemen berbasis sekolah adalah sejumlah praktisi di sekolah, yang terlibat dalam partisipasi membuat kebijakan dan keputusan untuk kepentingan lembaga. MBS dimulai dari desentralisasi, penyerahan wewenang yang jelas dari pusat ke daerah.

Suharsimi Arikumto, manajemen berbasis sekolah adalah penataan sistem pendidikan yang memberikan keleluasaan penuh kepada warga sekolah, memanfaatkan semua fasilitas dan media yang tersedia untuk menyelenggarakan pendidikan bagi siswa dan mampu mempertanggungjawabkan secara penuh. Lanjutnya dalam manajemen berbasis sekolah, wilayah sekolah bukan hanya terbatas sampai pagar sekolah dengan komunitasnya, tetapi meluas sampai lingkungan masyarakat setempat. Anggota organisasi sekolah tidak pula terbatas pada warga masyarakat lokal, tetapi semua orang yang punya kepedulian terhadap urusan sekolah meskipun berdomisili sangat jauh dari sekolah. ${ }^{15}$

Berdasarkan konsep para ahli tersebut, maka dapat didefinisikan MBS adalah model manajemen yang memberikan otonomi dan fleksibilitas lebih besar kepada sekolah untuk mengelola sumberdaya sekolah dan mendorong sekolah meningkatkan partisipasi warga sekolah dan masyarakat untuk mencapai tujuan mutu sekolah dalamkerangka pendidikan nasional. Oleh karena itu dapat disimpulkan esensi dari manajemen peningkatan

${ }^{13}$ Depag RI., Pedoman Manajemen Berbasis Madrasah. (Jakarta: Direktorat Jenderal Kelembagaan Agama Islam. 2004), h. 13

${ }^{14}$ Dornself, Alan. Pocket Guide to School-Based Managemen, (Alexandria: Virginia ASCD, 1996), h. 3

${ }^{5}$ Arikumto, Suharsimi. Manajemen Penelitian, (Jakarta: Rineka Cipta, 2005), h. 13 mutu berbasis sekolah (MPMBS) adalah otonomi sekolah, kemandirian, fleksibilitas, peningkatan kewenangan, partisipasi, transparansi, akuntabilitas, keadilan dan kerjasama secara keberlanjutan untuk mencapai mutu pendidikan.

Adapun alasan programmanajemen peningkatan mutu berbasis sekolah di Indonesiaharusdiimplementasikan. Menurut Depdiknas;1)sekolah sebagai institusi pendidikan lebih mengetahui kelebihan, kelemahan, peluang dan ancaman bagi dirinya, sehingga dapat mengoptimalkan pemanfaatan sumberdaya yang tersedia untuk memajukan institusinya; 2) sekolah lebih mengetahui kebutuhan institusinya khususnya input pendidikan yang dikembangkan dan didayakan dalam proses pendidikan sesuai dengan kebutuhan institusi dan tingkat perkembangan anak didiknya; 3)pengambilan keputusan yang dilakukan sekolah sebagai institusi lebih cocok untuk memenuhi kebutuhan institusi karena mareka paling mengetahui yang terbaik bagi institusinya. ${ }^{16}$

Hasil penelitian menunjukkan pada 8 (delapan) MTsN/S di Kota Bengkulu, konsep manajemen peningkatan mutu berbasis sekolah (MPMBS) sudah dikenal dan sudah berjalan programnya, namun masih perlu mensosialisasikan program MPMBS kepada para guru, komite sekolah dan orang tua siswa, agar lebih memahami program tersebut. Mengingat hasil penelitian ada beberapa guru dan pengurus komite sekolah belum memahami tentang program MPMBS, baru sebatas mengenal istilahnya saja.

Temuan yang cukup menarik terkait pemahaman otonomi sekolah melalui pengambilan keputusan partisipatif yang melibatkan secara langsung semua warga sekolah (guru, siswa, kepala sekolah, karyawan, orang tua siswa dan masyarakat) untuk meningkatkan mutu sekolah berdasarkan kebijakan pendidikan nasional. Sekolah memiliki kewenangan lebih besar dalam mengelola sekolahnya, sehingga sekolah lebih mandiri. Temuan yang cukup membanggakan dan mengharukan dari dewan pendidikan yang sempat diinterview di Kantor Kementerian Agama Kota Bengkulu mengatakan bahwa MTsN di Kota Bengkulu telah menerapkan manajemen baru walaupun belum disubsidi oleh pemerintah seperti

${ }^{16}$ Depdiknas. Manajemen Berbasis Sekolah. (Jakarta: Direktorat Jenderal Pendidikan Dasar dan Menengah, 2004), h. 3 
dana BOMM atau school grant sebagai pancingan pembiayaan peningkatan mutu, namun mareka tetap menerapkan program manajemen peningkatan mutu berbasis sekolah ini,secara mandiri.

Kemandirian MTs melalui pemberdayaan sumberdaya manusia (SDM) dan sumberdaya alam (SDA) yang ada di sekolah. Contohnya program MPMBS yang sudah diterapkan di MTs adalah dengan membuka kolam ikan, kebun kelapa, koperasi sekolah, kantin/warung, unit simpan pinjam dan unit usaha kerajinan tangan. Program tersebut diharapkan MTs dapat diberdayakan, ini merupakan sumberdana, yang dapat memberikan kesejahteraan dan bisa membantu pelaksanaan program MPMBS di MTs ini. Menurut kepala MTs untuk mendapatkan pendidikan yang bermutu membutuhkan anggaran yang cukup, kalau kita minta kepada masyarakat ujung-ujungnya dapat masalah. Tidak sedikit masalah yang dihadapi bersumber dari faktor manajemen ketertutupan penyelenggaraan kepemimpinan, sehingga banyak menghabiskan enargi dalam mengatasinya, akibat tidak transparansi.

Transparansi yang diterapkan pada MTs Kota Bengkulu menurut kepala madrasah bahwa pengelolaan madrasah, telah menyusun rencana dan program kerja bersama guru, karyawan, komite sekolah, memiliki jangka waktu, menentukan sumberdana, rasionalitas, skalaprioritas, menentukan program dan rinciannya, menetapkan kebutuhan, menghitung dana yang dibutuhkan dan dikelola dengan transparan. Dan temuan pada MTs yang lain di Kota Bengkulu, pengelolaan keuangan sifatnya transparan. Penggunaan keuangan adalah kepala sekolah, yang melaksanakan programnya adalah bendahara dan tata usaha. Penggunaan keuangan sesuai dengan aturan, acuan dan buku panduan dari pemerintah. Contohnya kalau ada bantuan dibentuk tim pengelolanya seperti BOP, BOS dan BSM, ada tim yang mengurus keuangannya dan kepala madrasah bertanggungjawab dan memantau kinerja tim tersebut. Memberikan tanggungjawab kepada mareka.

Tanggungjawab menunjukkan bahwa MTs di Kota Bengkulu telah menerapkan azas akuntabilitas (tanggngjawab), secara kualitas belum optimal dalam pelaksanaannya. Contohnya dalam pengelolaan keuangan ada penanggungjawab tiap pos kegiatan pembiayaan berdasarkan kesepakatan bersama warga madrasah dan keputusan kepala madrasah, pembiayaan berdasarkan aturan, pedoman dan mekanisme yang ada, realisasi kegiatan sesuai perencanaan sebelumnya, sasaran yang dibiayai kegiatan akademik dan non akademik. Pengelolaan keuangan adanya keseimbangan besarnya pengeluaran dan pemasukan, ada buku uang pemasukan dan uang pengeluaran secara lengkap. Ada dokumen pembelanjaan atau pengeluaran, seperti kuitansi, nota pembelian barang, ada perangkat pelaporan pengeluaran anggaran, ada personil penanggungjawab keuangan secara keseluruhan. Madrasah memiliki akuntabilitas yaitu bentuk pertanggungjawaban dilakukan madrasah terhadap keberhasilan program yang telah dilaksanakan. Akuntabilitas itu berbentuk laporan prestasi yang dicapai dan dilaporkan kepada pemerintah, orang tua, siswa dan masyarakat.

Azas partisipasi pada MTs Kota Bengkulu ada 2 (dua) bentuk yaitu; 1) partisipasi non material seperti orang tua jarang menyediakan waktu yang cukup untuk mendidik anak-anaknya misal mengawasi kedisiplinan anak bersekolah, belajar, mengerjakan PR, bermain dan menonton TV; 2) parisipasi material, seperti jarang ada orang tua menyediakan ruang belajar khusus yang cukup memenuhi syarat untuk digunakan sebagai tempat belajar anak-anaknya. Jangankan menyediakan ruang, alat-alat sekolah, bahkan ada anggapan yang sangat mendalam bahwa sekarang ini sekolah gratis, jadi mareka datang ke sekolah meminta baju seragam, sepatu sekolah dan tas sekolah. Untuk menyelesaikan hal ini, perlu kerjasama dengan pihak-pihak terkait untuk meningkatkan partisipasi orang tua siswa.

Azas kerjasama MTs Kota Bengkulu dengan pihak-pihak terkait dalam upaya peningkatan mutu pendidikan seperti pemerintah, orang tua siswa, komite dan masyarakat dengan menyelenggarakan pertemuan rutin ketika membagi raport, rapat komite dan pertemuan lain sesuai kebutuhan. Hasil penelitian menunjukkan bahwa pada MTs Kota Bengkulu telah melakukan jalinan kerjasama yang baik dalam proses tersebut, namun secara parsial, hanya ada satu aspek yang harus lebih dikembangkan dan ditingkatkan kualitasnya, yaitu peran pemerintah daerah dan masyarakat terutama komunikasi dan pembinaan.

Azas sustainibilitas menunjukkan bahwa MTs di Kota Bengkulu telah menerapkan azas sustaini- 
bilitas/ peningkatan mutu secara bertahap, namun semenjak digulirkannya program MPMBS azas sustainibilitas lebih ditingkatkan. Contohnya dalam penyelenggaraan pendidikan di MTs di Kota Bengkulu, terlihat dalam penyusunan program program peningkatan mutu madrasah, walaupun di MTs Kota Bengkulu mengalami pergantian kepemimpinan, komitmen yang tertuang dalam visi, misi, tujuan dan sasaran madrasah serta pengembangan mutu pendidikan pada masa datang tidak dirubah secara menyeluruh, namun jika tujuan dan sasaran yang diinginkan tidak tercapai maka hal demikian baru dirubah.

Berdasarkan hal tersebut manajemen peningkatan mutu berbasis sekolah yang sedang dikembangkan di Indonesia lebih menekankan pada pemberian otonomi, kewenangan, kemandirian, transparansi, akuntabilitas, kerjasama, partisipasidan sustainibilitas kepada madrasah untuk mengelola dan mengembangkan sumberdaya pendidikan dalam upaya meningkatkan mutu pendidikan di madrasah masing-masing serta mempertanggungjawabkan hasilnya kepada orang tua siswa, masyarakat, pemerintah dan koridor kebijakan pendidikan nasional, untuk meningkatkan mutu pendidikan.

Manfaat manajemen peningkatan mutu berbasis sekolah (MPMBS) menurut Kementerian Agama. Memberikan kebebasan dan kewenangan yang luas kepada madrasah disertai seperangkat tanggungjawab, pengelolaan sumberdaya dan pengembangan strategi PBM sesuai dengan kondisi setempat, keleluasaan dalam mengelola sumberdaya dan partisipasi masyarakat, mendorong profesionalisme kepemimpinan madrasah untuk berimprovisasi dan berinovasi melakukan berbagai eksperimentasi di lingkungan madrasah. Dengan demikian, target utama manajemen peningkatan mutu berbasis sekolah adalah pemberdayaan sekolah untuk mandiri dalam meningkatkan mutu pendidikan. Kemampuan dan manajemen kepemimpinan kepala sekolah serta ketersediaan sumberdaya yang memadai merupakan persyaratan bagi keberhasilan pelaksanaan manajemen peningkatan mutu berbasis sekolah (MPMBS).

\section{Karakteristik Manajemen Peningkatan Mutu Ber- basis Sekolah (MPMBS)}

Karakteristik manajemen peningkatan mutu berbasis sekolah (MPMBS) menurut Kementerian Agama adalah; 1) pengelolaan madrasah desentralistik pemberian otonomi luas; 2) perubahan madrasah akan lebih didorong oleh motivasi internal daripada diatur oleh luar madrasah; 3) regulasi pendidikan menjadi lebih sederhana; 4) peranan para pengawas bergeser dari mengontrol menjadi mempengaruhi dari mengarahkan menjadi memfasilitasi dan dari menghindari resiko menjadi mengelola resiko; 5) akan mengalami peningkatan manajemen; 6) dalam bekerja akan menggunakan team work; 7) pengelolaan informasi akan lebih mengarah ke semua kelompok kepentingan madrasah; 8) manajemen madrasah lebih menggunakan pemberdayaan dan struktur organisasi akan lebih datar sehingga akan lebih sederhana, efektif dan efisien. ${ }^{17}$

Sekolah memberikan kesempatan dan jaminan kepada warga sekolah untuk menjalankan kewajiban dan memperoleh hak-haknya sesuai dengan tujuan sekolah dan potensisekolah atau daerah. Sekolah memberikan penghargaan kepada warga sekolah yang dipertimbangkan telah berprestasi atau berjasa. Sekolah memberikan sanksi kepada tiap warga sekolah yang melanggar tugas pokok, fungsi, kewajiban dan tanggungjawab sesuai ketentuan kelembagaan.

Sekolah melakukan usaha untuk selalu memperbaiki peraturan-peraturan (baik akademik maupun non akademik) untuk meningkatkan mutu pendidikan, seperti kedisiplinan, tatakrama dan lain sebagainya. Memberikan kesempatan yang demokratis kepada warganya untuk berpartisipasi dalam pembuatan kebijakan atau peraturan. Dalam upaya sosialisasi dan implementasi program MPMBS, sekolah/madrasah membuat kebijakan yang mengharuskan adanya peran aktif semua warga sehingga tujuan mutu dapat tercapai.

Setelah implmentasi program MPMBS terdapat peningkatan kebiasaan baik di madrasah seperti; peningkatan kedisiplinan warga, pergaulan dan suasana kondusif, ketaatan pada peraturan. Dengan adanya program MPMBS yang dijalankan, memberikan dampak pada kebiasaan bagi warga madrasah untuk melakukan perubahan yang mengarah kepa-

${ }^{17}$ Depag RI., Pedoman Manajemen Berbasis Madrasah. (Jakarta: Direktorat Jenderal Kelembagaan Agama Islam. 2004), h. 15-17 


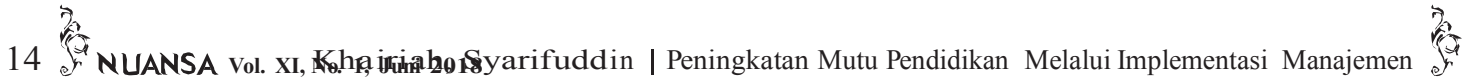

da peningkatan mutu pendidikan, misalnya inovasi pembelajaran, peralatan/sarpras dan inovasi bahan ajar.

Dengan adanya program MPMBS, diharapkan peningkatan peran warga sekolah dalam bidang akademik. Para siswa lebih giat mengikuti akademik/ PBM maupun kegiatan non akdemik. Ada peningkatan komitmen dan kinerja pegawai. Para warga madrasah memberikan masukan berupa pemikiran, material dan finansial,sehingga terjamin sinergitas madrasah.

Program kerja MPMBS dengan berbagai strategi yang dijalankan didasarkan atas analisa SWOT. Dari analisa SWOT diperoleh berbagai faktor pendukung dan penghambat program kerja, sehingga dapat mempermudah menentukan strategi pelaksanaan program,sehingga efektifitas proses belajar mengajar tinggi. Sekolah yang menerapkan MPMBS memiliki efektifitas proses belajar mengajar (PBM) yang tinggi. Hal itu ditunjukkan oleh sifat PBM yang menekankan pada pemberdayaan peserta didik. Pembelajaran bukan sekedar penekanan pada penguasaan tertentu, tetapi lebih menekankan manfaat pengetahuan dipelajari, sehingga berfungsi sebagai muatan nurani dan dihayati serta dipraktekkan dalam kehidupan sehari-hari oleh peserta didik. Disamping ituPBM yang efektif lebih menekankan pada learning to know, learning to do, learning to live together dan learning to be.

Madrasah melakukan evaluasi dan perbaikan secara berkelanjutan, untuk mengetahui daya serap dan tingkat kemampuan peserta didik, serta memanfaatkan hasil evaluasi belajar tersebut untuk memperbaiki proses belajar mengajar. Oleh karena itu fungsi MPMBS menjadi sangat penting dalam rangka meningkatkan mutu peserta didik dan mutu pendidikan secara keseluruhan dan secara terus menerus.Perbaikan secara terus menerus harus menjadi kebiasaan warga madrasah. Tiada hari tanpa perbaikan. Karena itu sistem mutu sebagai acuan perbaikan harus ada. Maksud sistem mutu mencakup struktur organisasi, tanggungjawab, prosedur, proses dan sumberdaya untuk menerapkan manajemen mutu.

Implementasikan program MPMBS harus sadar bahwa budaya mutu harus tertanam dihati sanubari warga madrasah, sehingga setiap perilaku selalu didasari oleh profesionalisme. Budaya mutu mempunyai elemen sebagai berikut ; 1) informasi kuali- tas harus digunakan untuk perbaikan, bukan untuk mengontrol SDM; 2) kewenangan harus sebatas tanggungjawab; 3) hasil harus diikuti reward dan punishment; 4) warga madrasah merasa aman terhadap pekerjaannya; 5) atmosfir keadilan harus ditanamkan; 6) imbal jasa harus sepadan dengan nilai pekerjaannya; 7) warga madrasah merasa memiliki madrasah.

Madrasah responsive dan antisipatif terhadap kebutuhan dan berbagai aspirasi yang muncul bagi peningkatan mutu. Selalu membaca lingkungan dan menanggapinya secara cepat dan tepat, bahkan tidak hanya mampu menyelesaikan perubahan atau tuntutan, tetapi juga mampu mengantisipasi halhal yang mungkin bakal terjadi. Menjemput bola adalah padanan kata yang tepat bagi istilah antisipatif. Memiliki kemauan berubah. Perubahan atau inovasi harus merupakan sesuatu yang menyenangkan bagi semua warga madrasah. Sebaliknya status quo merupakan musuh sekolah. Tentu saja yang dimaksud dengan perubahan adalah peningkatan, baik bersifat fisik mupun psikologis. Artinya setiap dilakukan perubahan, hasilnya diharapkan lebih baik dari sebelumnya atau ada peningkatan terutama mutu peserta didik.

Madrasah memiliki azassustainabilitas. Madrasah yang menerapkan MPMBS harus memiliki kemampuan untuk menjaga kelangsungan hidupnya (sustainabilitasnya), baik dalam program maupun pendanaannya. Sustainabilitas program dapat dilihat dari keberlanjutan program yangdirintis sebelumnya dan bahkan berkembang menjadi program baru yang belum pernah ada sebelumnya. Sustainabilitas pendanaan dapat ditunjukkan oleh kemampuan sekolah dalam mempertahankan besarnya anggaran yang dimiliki dan bahkan makin besar jumlahnya.Madrasah memiliki kemampuan sustainabilitas yang tinggi karena di madrasah tersebut terjadi proses akumulasi peningkatan mutu sumberdaya manusia, diverifikasi sumberdana, pemilikan asset mampu menggerakkan income generating activities dan dukungan yang tinggi dari masyarakat terhadap eksistensi madrasah.

\section{Operasionalisasi Program Manajemen Peningka- tan Mutu Berbasis Sekolah (MPMBS)}

Menurut Kemendikbud strategi pokok operasional MPMBS meliputi; 1) sosialisasi program menuju keterbukaan; 2) melakukan evaluasi diri 
untuk mengidentifikasi tantangan nyata; 3) merumuskan visi, misi dan target mutu; 4) menyusun rencana peningkatan mutu; 5) melaksanakan rencana peningkatan mutu; 6) melakukan monitoring dan evaluasi pelaksanaan; dan 7) merumuskan target mutu. ${ }^{18}$

Pertama, Sosialisasi Program. Bagi sekolah yang akan mengimplementasikan program MPMBS, maka perlu mensosialisasikan konsep MPMBS tersebut kepada semua unsur warga sekolah dan stakeholdersyang terkait, melalui berbagai mekanisme seperti; seminar, lokakarya, orientasi, work shop, sarasehan, diskusi dan rapat kerja.

Kedua, Melakukan Evaluasi Diri. Langkah selanjutnya dalam implementasi konsep Manajemen Peningkatan Mutu Berbasis Sekolah (MPMBS) adalah melakukan evaluasi diri sendiri. Dengan melakukan evaluasi diri sendiri, sekolah melahirkan gambaran nyata keadaan sekolah yang sesungguhnya, hal ini sering disebut dengan istilah profil sekolah. Hal-hal yang dievaluasi meliputi kelemahan dan kekuatan tentang; 1) prestasi sekolah yang telah dicapai selama ini; 2) sumberdaya pendidikan yang tersedia disekolah; 3) dukungan orang tua dan masyarakat sekitar terhadap penyelenggaraan pendidikan.

Ketiga, Merumuskan Visi, Misi dan Target Mutu. Warga sekolah ataustakeholders yang terkait melakukan langkah yaitu merumuskan visi, misi dan target mutu yang dicapai sekolah dalam kurun waktu tertentu. Visi adalah sesuatu yang idial yang dicapai sekolah dimasa datang. Untuk mencapai tujuan yang tertuang dalam visi, maka sekolah perlu merumuskan misi yang ditempuh sekolah dalam menyelenggarakan layanan pendidikankepada masyarakat. Misi adalah layanan pendidikan seperti yang diberikan kepada siswauntuk mencapai visi yang diterapkan. Berdasarkan visi dan misi sekolah yang telah diterapkan maka dirumuskan target mutu pendidikan yang dicapai oleh sekolah untuk kurun waktu tertentu.

Keempat, Menyusun Rencana Peningkatan Mutu. Rencana menjelaskan secara detail dan lugas tentang aspek mutu yang ingin dicapai, kegiatankegiatan yang harus ditempuh, yang harus melaksanakan dan memperoleh dukungan dari orang tua

${ }^{18}$ Depdiknas. Manajemen Berbasis Sekolah. (Jakarta: Direktorat Jenderal Pendidikan Dasar dan Menengah, 2004), h. 3 siswa baik secara moral maupun fisik untuk melaksanakan rencana peningkatan mutu pendidikan tersebut. Yang perlu diperhatikan dalam menyusun rencana program adalah keterbukaan kepada semua pihak yang menjadi stakeholderspendidikan, khususnya orang tua dan masyarakat pada umumnya. Dengan demikian diperoleh kejelasan, berapa kemampuan sekolah dan pemerintahuntuk menanggung program ini dan berapa sisanya yang harus ditanggung oleh orang tua dan masyarakat sekitarnya. Dengan keterbukaan manajemen maka kemungkinan kesulitan memperoleh sumberdana untuk melaksanakan program dapat diselesaikan.

Kelima, Melaksanakan Rencana Peningkatan Mutu. Dalam melaksanakan rencana program peningkatan mutu pendidikan yang telah disetujui bersama antar sekolah, orang tua dan masyarakat, maka sekolah perlu mengambil langkah proaktifuntuk mewujudkan target-target yang telah ditetapkan.

Keenam, Melakukan Monitoring dan Evaluasi Pelaksanaan. Untuk mengetahui tingkat keberhasilan program sekolah perlu mengadakan evaluasi pelaksanaan program baik jangka pendek, jangka menengah dan jangka panjang. Evaluasi jangka pendekdilakukan setiap akhir semester untuk mengetahui keberhasilan program secara bertahap, jika pada semesteran dinilai adanya faktor-faktor yang tidak mendukung, maka sekolah harus bisa memperbaiki pelaksanaan program peningkatan mutu pada semesteran berikutnya. Evaluasi jangka panjang dilakukan pada akhir tahun untuk mengetahui program peningkatan mutu telah mencapai target-target mutu yang ditetapkan sebelumnya, dengan evaluasi ini diketahui kelebihan dan kelemahan program untuk diperbaiki tahun berikutnya.

Ketujuh, Merumuskan Target Mutu. Berdasarkan hasil dari penilaian dapat memperbaiki kinerja program di masa datang. Hasil penelitian merupakan input bagi sekolah dan orang tua untuk merumuskan target mutu di tahun depan. Jika dianggap berhasil target mutu dapat ditingkatkan dan jika tidak berhasil target mutu tetap seperti semula, namun dilakukan perbaikan strategi dan mekanisme pelaksanaan kegiatan program. Namun bisa saja terjadi target mutu diturunkan karena dianggap terlalu berat atau tidak sepadan dengan sumberdaya pendidikan (tenaga, sarana prasarana dan anggaran) yang tersedia. 


\section{Strategi Pelaksanaan}

\section{MPMBS Pendekatan}

Reformasi manajemen pendidikan persekolahan, menggunakan pendekatan model MPMBS merupakan tuntutan yang mendesak, kompleksitas masa depan pendidikan dituntut harus makin bermutu dan berkualitas sesuai dengan harapan masyarakat. Sementara ini sekolah ditempatkan pada posisi subordinasi, kurang berdaya, karena hampir semua operasional pendidikan ditentukan oleh pendekatan birokratis secara struktural, topdown, sehingga tenaga pengelola kependidikan menjadi kaku dan terpasung kepada aturan dan kebijakan yang ada.

Upaya mengatasi kesalahan tersebut, maka MPMBS merupakan satu alternative pemecahan terhadap permasalahan di sekolah. Dengan MPMBS sekolah diharapkan mampu meningkatkan mutu pendidikan sebagai wujud akuntabilitas publik. Namun ada sejumlah faktor lain yang mempengaruhi keberhasilan MPMBS, misalnya tingkat ekonomi masyarakat, sosial budaya, politik dan taraf pendidikan masyarakat, kebijakan pemerintah, organisasi/ kepemimpinan kepala sekolah, manajemen PBM di kelas, administrasi sekolah, SDMprofesionalisme guru dan tenaga lainnya.Haltersebut merupakan komponen atau aspek yang perlu diperhatikan dalam konteks persekolahan yang berdasarkan MPMBS. Ada 6 (enam) persyaratan yang perlu dipenuhi dalam strategi pelaksanaan MPMBS, antara lain: 1) rekrutmen kepala sekolah dan guru professional; 2) bentuk partisipasi dasar orang tua siswa; 3) motivasi/kemauan dasar orang tua siswa; 4) kemampuan mengalokasikan dana/keuangan sekolah; 5) kualitas KBM, hasil lulusan dan outcome; dan 6) keterlibatan semua stakeholders pendidikan.

\section{Metode}

Dalam Implementasi MPMBS, sekolah dapat mengimplementasi metode "idiografik" (membolehkan kebebasan operasional MPMBS). Walaupun dalam beberapa hal masih menggunakan metode "nomotetik" pada pelaksanaan MPMBS berkaitan dengan waktu pelaksanaan, program kegiatan, memperhatikan ketentuan standar pelayanan minimum yang ditetapkan secara nasional.

Pada dasarnya MPMBS dapat dilaksanakan secara bertahap dengan memperhatikan kondisi sekolah dan kondisi sosial masyarakat serta mem- pertimbangkan faktor giografis, demografis, budaya setempat dan potensi sumberdaya yang dimiliki masyarakat dan sekolah.

\section{Prinsip dan Alasan Implementasi MPMBS}

Prinsip Umum

Ada 6 (enam) prinsip umum yang menjadi pijakanimplementasi MPBS; 1) memiliki visi kearah pencapaian mutu pendidikan khususnya mutu siswa sesuai jenjang sekolah;2) berpijak pada power sharing (pembagian kewenangan), pengelolaan pendidikan sepatutnya berlandaskan pada adanya saling mengisi dan berbagi kekuasaan/kewenangan sesuai dengan fungsi dan peran masing-masing; 3) adanya profesionalisme semua lini; 4) melibatkan partisipasi masyarakat yang kuat. Maksudnya tanggungjawab pelaksanaan pendidikan, bukan hanya dibebankan kepada kepala sekolah, guru dan tenaga administrasi saja, tetapi juga menuntut keterlibatan dan tanggungjawab komponen masyarakat lainnya termasuk orang tua dan masyarakat; 5) terbentuknya dewan sekolah. Artinya dalam implementasi MPMBS, sekolah/madrasah berkewajiban membentuk dewan sekolah, sebagai institusi yang melaksanakan MPMBS. Pembentukan dewan sekolah merupakan prasyarat terlaksananya program MPMBS; 6) adanya transparansi dan akuntabilitas. Maksudnya adalah bahwa prinsip MPMBS harus berpijak pada transparansi atau keterbukaan dalam pengelolaan sekolah, termasuk didalamnya masalah fisik dan non fisik. Sedangkan akuntabilitastanggungjawab, bahwa sekolah beserta dewan sekolah merupakan institusi terdepan yang paling bertanggungjawab dalam pengelolaan sekolah.

\section{Alasan Implementasi Program MPMBS}

MPMBS dilaksanakan dengan pertimbangan sebagai berikut; 1) supaya sekolah mengetahui posisi atau kekuatan, kelemahan, peluang dan ancaman bagi dirinya, sehingga ia dapat mengoptimalkan pemanfaatan sumberdaya yang tersedia untuk memajukan sekolahnya; 2) supaya sekolah dapat mengetahui tingkat kebutuhan lembaganya, khususnya masukan pendidikan yang dikembangkan dan didayagunakan dalam proses penidikan sesuai dengan tingkat perkembangan dan kebutuhan siswa; 3) supaya keputusan yang dilakukan sekolah lebih dapat memenuhi kebutuhan sekolah; 4) supaya penggunaan sumber daya pendidikan dapat 


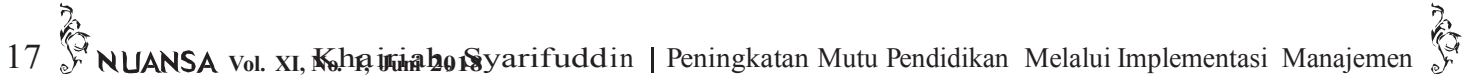

secara efektif dan efisien jika dilakukan kontrol oleh masyarakat; 5) keterlibatan dewan sekolah dalam pengambilan keputusan dapat menumbuhkan budaya transparansi dalam pengelolaan dana atau biaya pendidikan dan menumbuhkan sikap demokratis; 6) supaya sekolah bertanggungjawab secara langsung dalam mempertanggunjawabkan mutu pendidikan kepada stakeholders; 7) supaya sekolah memiliki daya saing atau competitivinees diantara sekolah yang ada secara sehat dan terbuka, dalam hal inovasi untuk meningkatkan mutu pendidikan; 8) supaya sekolah lebih cepat merespon terhadap kebutuhan atau aspirasi masyarakat setempat sesuai dengan perkembangan zaman.

\section{Strategi Memacu Peningkatan Mutu Pendidikan}

Pertama, Anggaran dan Penyiapan sumber daya manusia (SDM), setiap kali membahas strategi meningkatkan mutu pendidikan, acuannya adalah penyediaan sumber pendanaan yang cukup atau bahkan berlebih. Rendahnya mutu pendidikan dikorelasikan dengan minimnya anggaran tersedia yang disediakan pemerintah. Begitu juga kualitas SDM pengelola pendidikan, dipersepsikan sangat tergantung pada tingkat kesejahteraan dan gaji para guru.Mutu pendidikan sulit dicapai tanpa dukungan sumber pendanaan cukup. Namun pada saat persentase anggaran pendidikan baik dari APBN dan APBD masih terasa minim, mengupayakan mutu pendidikan tidak harus terus berkutat pada perjuangan menaikkan persentase anggaran. Ada hal lain yang perlu ditangani yaitu pengelolaan anggaran secara lebih transparan jauh lebih strategis dibandingkan berjuang mencari tambahan anggaran tanpa rencana program pendidikan yang jelas. Strategi ini tampak jelas terutama pada madrasah dan perguruan tinggi swasta, meskipun masyarakat harus menanggung hampir seluruh anggaran, namun karena program dan mutu pendidikan terukur jelas, besar kecilnya anggaran tidak menjadi persoalan. Efisien dan efektifkah suatu anggaran bagi pencapaian mutu pendidikan menjadi tolak ukur dukungan masyarakat, terutama para orang tua terhadap lembaga pendidikan. Kuncinya adalah masyarakat tahu, besarnya anggaran pendidikan karena memang betul-betul untuk peningkatan mutu pendidikan dan terkait dengan proses belajar mengajar dan bukan intervensi kepentingan komersial dalam lembaga pendidikan.
Kedua, Meningkatkan Mutu Manajemen. Persoalan teknik edukatif untuk mengimplementasikan rencana strategis tersebut lebih banyak memberikan peran kepala sekolah/madrasah, karena mareka menangani langsung unit inti penyelenggara pendidikan. Keberhasilan madrasah mengangkat mutu pendidikan sesuai visi dan misinya banyak ditentukan oleh kemampuan kepala madrasah menguasai manajemen pendidikan. Efektif tidaknya MPMBS banyak tergantung kepemimpinan kepala sekolah/madrasah, dengan asumsi kepala madrasah menjadi kunci berfungsi tidaknya manajemen madrasah. Begitu juga dengan pembentukan komite madrasah untuk mendukung eksistensi madrasah sebagai lembaga yang mandiri dengan kewenangan otonomi dalam manajemen, kepala madrasah memegang peranan penting. Mengingat kepala madrasah merupakan kunci dalam implementasi program MPMBS, maka pengangkatannyapun perlu melibatkan warga madrasah, selama ini pengangkatan kepala madrasah sering mengundang spekulasi dan kecurigaan masyarakat atas terjadinya KKN (korupsi, kolusi dan nepotisme) karena prosesnya yang kurang transparan. Proses rekrutmen kepala madrasah telah mengeleminir keresahan di kalangan guru yang selama ini menuding para kepala madrasah sebagai pelaku KKN, baik pada saat diangkat dengan menyuap maupun setelah menjabat melakukan KKN anggaran. Partisipasi adalah kunci keberhasilan MPMBS dan kepala madrasah yang bersikap demokratis karena diangkat melalui proses yang demokratis pula, mudah membangun partisipasi warga madrasah. Dari sinilah peningkatan mutu manajemen sekolah harus dimulai untuk menjangkau peningkatan mutu pendidikan.

Ketiga, Partisipasi dan Dukungan Pemberdayaan Masyarakat Mutu Pendidikan. Agar madrasah bisa bermutu, masyarakat harus berpartisipasi dalam bentuk sumbangan ke madrasah. Ini dapat mengundang kontradiksi dengan isu-isu politik untuk menjual program partai dengan wacana "pendidikan gratis" dan sebagainya. Persoalansemakin sulit ketika mempertahankan kondisi madrasah yang ada, pemerintah kesulitan, jangankan bicara soal mutu, mempertahankan madrasah yang tidak bermutupun sulit, karena pemerintah tidak punya cukup anggaran. Namun disinilah justru muncul potensi masyarakat setelah tahu kondisi yang dihadapi pemerintah. Dengan demikian dukungan dan 


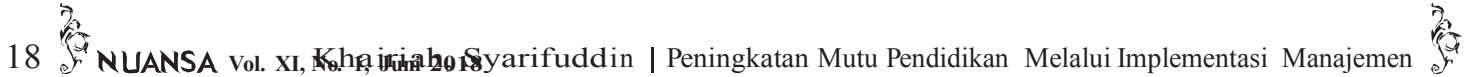

partisipasi masyarakat untuk perbaikan sarana prasarana terhadap peningkatan mutu pendidikan secara umum, ini menjadi prakondisi bagi masyarakat pendidikan dalam mengimplementasikan strategi program MPMBS.

Keempat, Pemerintah Daerah Meningkatkan Mutu Pendidikan. Strategi Pemerintah Daerah dalam memacu kualitas madrasah melalui manajemen pendidikan adalah mendorong madrasah dari tingkat SD/MI, SLTP/MTs hingga SLTA/MA untuk mampu menerapkan Manajemen Peningkatan Mutu Berbasis Sekolah (MPMBS). Namun untuk implementasi MPMBS secara efektif masih diperlukan beberapa strategi; 1) membangun kepercayaan masyarakat terhadap madrasah sebagai lembaga pendidikan yang mampu menghasilkan keluaran (out put) secara memadai dari segi akademik, kompetensi dan tuntutan dunia kerja serta kepribadian peserta didik mampu hidup bermasyarakat; 2) mengelola manajemen pendidikan di daerah melalui peningkatan efektifitas Dinas Pendidikan secara lebih dinamis sehingga mampu menjadi fasilitator dan pembina bagi implementasi MPMBS di madrasah; 3) mengelola SDM di lingkungan kependidikan, khususnya penempatan kepala madrasah, sebagai pelaku dinamis penyelenggaraan pendidikan yang bermutu, dengan pola rekrutmen secara demokratis sehingga mendapat dukungan masyarakat madrasah; 4) menggerakkan partisipasi dan memberdayakan masyarakat dalam komunitas madrasah dengan melibatkan tokoh masyarakat setempat dan pemerintah setempat, mengefektifkan komite sekolah sehingga peningkatan mutu sekolah terarah sesuai tingkat kemandirian dan kebutuhan masyarakatnya; 5) menyiapkan dan menggali anggaran seoptimal mungkin dari berbagai sumber bagi upaya peningkatan mutu SDMdi tiap madrasah.

Kelima, Kesiapan Sekolah untuk MPMBS. Hasil penelitian Khairiah menunjukkan bahwa sebagian besar sekolah belum siap untuk MPMBS namun sebagian kecil ternyata bisa. Dan ini tidak hanya dalam lingkungan masyarakat kaya atau mampu, tetapi dapat ditemukan pada Kota kecil dengan lingkungan masyarakat yang relative sederhanan. ${ }^{19}$

${ }^{19}$ Khairiah. Implementasi Manajemen Peningkatan Mutu Berbasis Sekolah (MPMBS) Dalam Upaya Peningkatan Mutu Pendidikan MTsN Di Kota Bengkulu. (Bengkulu; Program Magister Manajemen Pendidikan Universitas Bengkulu, 2006), h. 44
Inipun jika berdasarkan kekayaan sumber daya alam, industri dan keuangan yang kebetulan tersedia, disinilah masalahnya, dikira persoalan otonomi hanya modal uang dan kekayaan sumber alam, tidak terpikirkan bahwa otonomi memerlukan modal intelektual, kesehatan mental, keteguhan moral dan etik, menomorsatukan kepentingan dan pelayanan rakyat, tanpa ini semua kekayaan sumber alam akan habis, sebaliknya dengan modal intelektual, kesehatan mental, kekuatan moral dan etik, alam yang gersang akan berubah menjadi sumber kekayaan uang yang terus melimpah.

Keenam, Kesiapan Masyarakat dalam Mendukung MPMBS. Menurut Hamijoyo, 1) karakteristik kemiskinan-kebodohan-kepenyakitan masyarakat dengan kendala mentalitas, budaya dan keorganisasian dalam masyarakat umumnya juga kurang mendukung terlaksananya MPMBS yang otonom, masyarakat pada umumnya masih paternalistic, static tradisionalistik dan static; 2) Pemerintah Daerah dan dan DPRDnya sekarang ini belum sempat memikirkan strategi pendidikan jangka menengah dan panjang karena masih terlalu merepotkan diri dengan persoalan politik praktis jangka pendek dan pengumpulan serta pemanfaatan dana keuangan; 3) sumber keuangan masyarakat untuk pendidikan sekolah, terutama SD sejak awal 1970an mulai merosot; 4) inovasi atau kegiatan pembaharuan pendidikan sekolah kebanyakan tidak direncanakan dan dilaksanakan secara konsisten, batal atau berhenti sebelum berakar, sehingga para pelaku di lapangan kecewa; 5) jaringan sosial yang sangat vital untuk menjamin partisipasi masyarakat lokal guna mendukung pembaharuan pendidikan kurang dibangun secara efektif; 6) membangun sistem baru di atas sistem yang ada dan sudah lama terbentuk, biarpun menjadi suatu keharusan, dalam prakteknya justru menimbulkan resistensi dan akibatnya bisa sangat counter produtif; 7) inovasi atau pembaharuan pada umumnya mengandung resiko, resiko kerugian waktu, tenaga, uang, bahan, biarpun pada jangka panjang bisa memberi keuntungan. Justru menunggu hasil dalam waktu lama ini yang tidak dapat ditanggung oleh para pelaku yang kebanyakan kurang mampu atau kurang kuat dalam banyak hal; 8) proses pembelajaran di kalangan masyarakat kurang dikembangkan dalam kebanyakan pengelolaan pembaharuan, sehingga tidak terlalu mengherankan kalau proses pem- 
berdayaan masyarakat berjalan sangat lambat; 9) kepemimpinan dan keteladanan pimpinansangat dibutuhkan dalam mendukung MPMBS; 10) sekolah dengan manajemen berbasis masyarakat sesungguhnya perlu dikembangkan sebagai usaha kembar sebagai usaha komplementer dari MPMBS. Masyarakat lokal sendiri sudah cukup berdaya, jika tujuan ini terlaksana maka itulah petanda bahwa sekolah yang ber-MPMBS sudah mencapai kinerja puncak (top performance).

Ketujuh, Faktor Pendukung Keberhasilan MPMBS. Implementasi MPMBS sangat dipengaruhi beberapa faktor yang sifatnya internal maupun eksternal. Secara umum beberapa faktor pendukung MPMBS. Menurut Tim Pokja,School Based Management(2001;45); 1) kepemimpinan dan manajemen sekolah yang baik. Maksudnya MBS berhasil jika ditopang oleh kemampuan professional kepala sekolah dalam memimpin dan mengelola sekolah secara efektif dan efisien serta mampu menciptakan iklim organisasi yang kondusif untuk proses belajar mengajar; 2) kondisi sosial, ekonomi dan apresiasi masyarakat terhadap pendidikan. Maksudnya faktor eksternal turut menentukan keberhasilan MBS adalah tingkat pendidikan orang tua dan masyrakat. Kemampuan dalam membiayai pendidikan serta tingkat apresiasi dalam mendorong anak untuk terus menerus belajar; 3) dukungan pemerintah; 4) profesionalisme. Maksudnya faktor ini sangat strategis dalam upaya menentukan mutu dan kinerja sekolah. Tanpa profesionalisme kepala sekolah, guru dan pengawas, sulit dicapai PBM yang bermutu tinggi serta prestasi siswa.

Kedelapan, Hambatan dalam Implementasi Program MPMBS. Menurut Agus Darma, beberapa hambatan yang mungkin dihadapi pihak kepentingan dalam implementasi MPMBS; 1) tidak berminat untuk terlibat ; 2) tidak efisien, pengambilan keputusan yang dilakukan secara partisipatif, adakalanya menimbulkan frustasi dan sering kali lebih lamban dibandingkan dengan cara otokratis; 3) pikiran kelompok, setelah beberapa saat bersama, para anggota dewan sekolah kemungkinan besar semakin kohesif, disatu sisi hal ini berdampak positif, karena mareka saling mendukung satu sama lain, di sisi lain kohevisitas menyebabkan anggota terlalu kompromi, hanya karena merasa tidak enak berlinan pendapat dengan anggota lainnya; 4) memerlukan pelatihan, pihak-pihak yang berke- pentingan kemungkinan besar sama sekali belum berpengalaman menerapkan model yang rumit dan partisipatif, mareka kemungkinan besar tidak memiliki pengetahuan dan keterampilan tentang hakekat MPMBS sebenarnya; 5) kebingunan atas peran dan tanggungjawab baru, penerapan MPMBS mengubah peran dan tanggungjawab pihak-pihak yang berkepentingan. Perubahan yang mendadak kemungkinan besar menimbulkan kejutandan kebingungan, sehingga mareka ragu untuk memikul tanggungjawab pengambilan keputusan; 6) kesulitan koordinasi. Setiap penerapan model yang rumit dan mencakup kegiatan yang beragam mengharuskan adanya koordinasi yang efektif dan efisien. Tanpa itu, kegiatan yang beragam berjalan sendiri ke tujuannya masing-masing yang kemungkinan besar, menjauh dari tujuan sekolah. ${ }^{20}$

Jika pihak berkepentingan dilibatkan sejak awal, maka setiap hambatan ditangani sebelum implementasi MPMBS. Dua unsur penting adalah pelatihan yang cukup tentangMPMBS dan klarifikasi peran dan tanggungjawab serta hasil yang diharapkan kepada semua pihak yang berkepentingan.Warga sekolah harus menyadari bahwa adakala harapan yang dibebankan kepada sekolah terlalu tinggi. Pengalaman penerapannya di tempat lain menunjukkan bahwa daerah yang paling berhasil mengimplementasikan program MPMBS telah memfokuskan harapan mareka pada dua maslahat; 1) meningkatkan keterlibatan dalam pengambilan keputusan; dan2) menghasilkan keputusan lebih baik untuk peningkatan mutu pendidikan.

\section{Penutup}

Berdasarkan pembahasan dan temuan tersebut di atas, maka dapat ditarik kesimpulan, bahwa implementsi manajemen peningkatan mutu berbasis sekolah (MPMBS) pada MTs di Kota Bengkulu, baik implementasi azas otonomi, kewenangan, partisipasi, transparansi, akuntabilitas, pemerataan,keadilan dan azas sustainabilitas berpengaruh dalam upaya peningkatan mutu pendidikan. Ini berarti jika azas otonomi, kewenangan, partisipasi, transparansi, akuntabilitas, pemerataan, keadilan dan azas sustainabilitas secara berkelanjutan diterapkan dengan

\footnotetext{
${ }^{20}$ Agus, Dharma. Manajemen Supervisi. (Jakarta: Raja Grafindo Persada, 2005),
} 


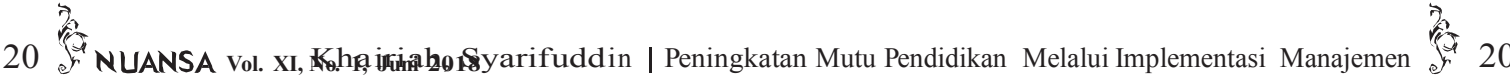

baik maka mutu pendidikan MTs baik negeri maupun swasta di Kota Bengkulu menjadi baik. Kesimpulan ini direduksi dari berbagai kajian, tulisan, buku, jurnal dan artikel ilmiah. Dengan demikian dapat disarankan, jika ingin memperbaiki mutu pendidikan madrasah, maka lakukan implementasi manajemen peningkatan mutu berbasis sekolah (MPMBS) pada MTs di Kota Bengkulu

\section{Daftar Pustaka}

Agus, Dharma. 2005. Manajemen Supervisi. Jakarta: Raja Grafindo Persada

Ahmady, Arifin, Zainal. 1995. Reformasi Adminitrasi dalam Pendidikan Beberapa Pelajaran tentang Implementasi Kebijakan. Pidato disampaikan pada Pengukuhan Jagatan Guru Besar dalam Ilmu Administrasi, Fakultas Administrasi Univrsitas Brawijaya Malang

Arikumto, Suharsimi. 2005. Manajemen Penelitian, Jakarta: Rineka Cipta

Azyumardi. 2002. Masalah dan Kebijakan Pendidikan Islamdi Era Otonomi Daerah. Makalah yang disampaikan pada konferensi Nasional Manajemen Pndidikan Yang Dilaksanakan di Hotel Indonesia Jakarta pada Tanggal 8 s.d 10 Agustus 2002

Bahrul, Hayat. 2013. Kumpulan Pidato, sekretaris Jenderal Kementerian Agama RI, Jakarta
Data Kantor Wilayah Kementerian Agama Provinsi Bengkulu Tahun 2006

Depdiknas. 2004. Manajemen Berbasis Sekolah. Jakarta: Direktorat Jenderal Pendidikan Dasar dan Menengah

Depag RI., 2004.Pedoman Manajemen Berbasis Madrasah. (Jakarta: Direktorat Jenderal Kelembagaan Agama Islam

Dornself, Alan. 1996. Pocket Guide to School-Based Managemen, Alexandria: Virginia ASCD

Fattah, Nanang, dkk. 2003.Manajemen Berbasis Sekolah, Jakarta: Universitas Terbuka Jakarta

Khairiah. 2006.Implementasi Manajemen Peningkatan Mutu Berbasis Sekolah (MPMBS) Dalam Upaya Peningkatan Mutu Pendidikan MTsN Di Kota Bengkulu. (Bengkulu; Program Magister Manajemen Pendidikan Universitas Bengkulu

Peraturan Pemerintah Nomor 28 Tahun 1990 tentang Pendidikan Dasar dan Pendidikan Menengah

Udoji. C.J.O. 1981. The African public servant as a public policy maker. Public Policy in Africa, African Association for Public Administration and Management

Undang-undang Nomor 22 Tahun 1999 tentang Otonomi Daerah

Undang-undang Nomor 20 Tahun 2003 tentang Sistem Pendidikan Nasional 
21 NUANSA Vol. XI, Kahạ inihahorgyarifuddin | Peningkatan Mutu Pendidikan Melalui Implementasi Manajemen 2 